\title{
PENILAIAN KINERJA DOSEN DALAM BIMBINGAN SKRIPSI
}

\author{
Siska Mayang Sari $^{1}$, Ennimay $^{2}$ \\ 1,2 Program Studi S1 Keperawatan, STIKes Hang Tuah Pekanbaru, Indonesia \\ Program Studi Ilmu Keperawatan STIKes Hang Tuah Pekanbaru Jalan Mustafa Sari No.5 Kampus 2 Pekanbaru Riau \\ Kode Pos 28288 Indonesia \\ email siskamyg@htp.ac.id
}

\begin{abstract}
Abstrak
Tenaga dosen sebagai salah satu komponen penting dalam Pendidikan Tinggi memiliki tugas dalam melaksanakan Tridharma Perguruan Tinggi salah satunya adalah membimbing tugas akhir/ skripsi dalam komponen melaksanakan pengajaran dan pendidikan. Skripsi merupakan tugas akhir yang harus diselesaikan mahasiswa pada program sarjana sebagai syarat memperoleh gelar Sarjana Keperawatan (S.Kep). Penelitian ini bertujuan untuk mengetahui hubungan penilaian kinerja dosen dalam bimbingan skripsi dengan kualitas skripsi. Metode penelitian yang digunakan adalah kuantitatif analitik, dengan desain korelasi dan pendekatan cross sectional. Populasi penelitian ini adalah seluruh lulusan S.Kep tahun ajaran 2019/2020 dan 2020/2021 yang masih terdaftar menjadi mahasiswa Ners yang berjumlah 77 orang. Teknik pengambilan sampel menggunakan total Sampling. Cara pengumpulan data menggunakan kuisioner dan telusur dokumen Skripsi pada prodi S1 Keperawatan. Analisis data menggunakan bivariat menggunakan Chi-Square. Hasil uji statistic didapatkan p-value 0,219 (>0,05) yang bermakna tidak terdapat hubungan antara kinerja dosen dalam bimbingan skripsi dengan kualitas skripsi mahasiswa berdasarkan persepsi mahasiswa. Meskipun demikian, diharapkan kepada prodi S1 Keperawatan STIKes Hang Tuah Pekanbaru untuk menerapkan penilaian kinerja dosen dalam bimbingan skripsi sebagai salah satu upaya evaluasi bimbingan skripsi dan kinerja dosen.
\end{abstract}

Kata kunci : Bimbingan, Kinerja dosen, Skripsi

\begin{abstract}
As one of significant indicators in higher education, lecture have to deliver the duty in the Tridharma of higher education include guidance in thesis. Thesis is one of the important condition that should passed by students to get the bachelor in nursing. This study aimed to find out the correlation between lecture appraisal performance in thesis guidance and thesis quality. This was a quantitative study with correlation design and cross sectional approach. The population were all graduated bachelor nursing students of STIKes Hang Tuah Pekanbaru. The sample was 77 participants which taken by total sampling technique. The instrument used questionnaire and document tracing. Data analyze used bivariate with chi-square test. The result of chi-square test showed p-value $0.219(>0.05)$ it mean there was no correlation between lecture appraisal performance in thesis guidance and thesis quality. Eventhough, it is recommended to Bachelor Nursing program of STIKes Hang Tuah Pekanbaru to held the evaluation of lecture appraisal performance in thesis guidance.
\end{abstract}

Keywords: Guidance, lecture appraisal performance, Thesis 


\section{PENDAHULUAN}

Pendidikan tinggi merupakan jenjang pendidikan setelah pendidikan menengah yang mencakup progam diploma, program sarjana, program magister, program doktor dan program profesi serta spesialis yang diselenggarakan oleh perguruan tinggi yang berdasarkan kebudayaan Indonesia (Presiden Republik Indonesia, 2012). Perguruan tinggi yang ada di Indonesia baik dibawah naungan negara/ Perguruan Tinggi Negeri (PTN) ataupun dikelola oleh Perguruan Tinggi Swasta (PTS) harus mengikuti peraturan nasional perguruan tinggi yang berlaku.

Mendikbud RI, (2020) menerangkan bahwa setiap perguruan tinggi mengikuti Standar Nasional Perguruan Tinggi (SN-PT). Sebagai satuan pendidikan yang menyelenggarakan Pendidikan Tinggi, perguruan tinggi mesti memenuhi SN-PT yang terdiri atas Standar Nasional Pendidikan; Standar Nasional Penelitian dan Standar Pengabdian kepada Masyarakat. Dalam melaksanakan standar ini perguruan tinggi diharapkan dapat mengkoordinasikan semua sistem yang terlibat didalamnya termasuk tenaga dosen sebagai salah satu komponen penting dalam Pendidikan tinggi.

Dosen merupakan pendidik professional dan ilmuwan dengan tugas utama mentransformasikan, mengembangkan dan menyebarluaskan ilmu pengetahuan, teknologi dan seni melalui pendidikan, penelitian dan pengabdian kepada masyarakat (Peraturan Pemerintah RI, 2009). Kemampuan dosen menjalankan tugas pendidikan, penelitian dan pengabdian kepada masyarakat atau Tri dharma perguruan tinggi menunjukkan keprofesionalannya. Tingkat keprofesionalan seorang dosen salah satunya dinilai dengan penilaian kinerja dosen.

Pada penilaian kinerja dosen yang terdapat beberapa aspek penting yang harus dilaporkan oleh seorang dosen yakni pelaksanaan pendidikan, pelaksanaan penelitian, pelaksanaan pengabdian kepada masyarakat dan kegiatan penunjang (Dikti, 2019). Salah satu sub penilaian dalam pelaksanaan pendidikan adalah membimbing skripsi.

Skripsi merupakan tugas akhir yang harus diselesaikan mahasiswa pada program 
sarjana di STIKes Hang Tuah Pekanbaru. Mata kuliah ini berada di semester akhir dan memiliki bobot 4 Satuan Kredit Semester (SKS). Untuk mengikuti mata kuliah ini mahasiswa harus mengikuti persyaratan yang telah ditetapkan oleh pihak program studi keperawatan. Setelah memenuhi persyaratan mahasiswa kemudian mengajukan judul dan akan dibimbing oleh dua orang dosen pembimbing yakni pembimbing satu dan pembimbing dua (Program Studi Sarjana Keperawatan STIKes Hang Tuah Pekanbaru, 2018).

STIKes Hang Tuah Pekanbaru (HTP) merupakan salah satu perguruan tinggi swasta yang adalah lingkungan Lembaga Layanan Pendidikan Tinggi (LLDIKTI) wilayah 10 Sumatera Barat, Riau, Kepulauan Riau dan Jambi. Sebagai PTS STIKes HTP telah memperoleh nilai B untuk Akreditasi Institusi Perguruan Tinggi (AIPT) dan seluruh program studinya terakreditasi B. Hal ini tentunya tidak lepas dari peran tenaga dosen yang telah menjalankan tugas tridharma perguruan tingginya. Program studi Sarjana Keperawatan sebagai salah satu program studi yang ada di STIKes HTP telah meluluskan mahasiswa sejak tahun 2010. Sebelum memperoleh gelar sarjana keperawatan seorang mahasiswa wajib menyelesaikan mata kuliah skripsi yang merupakan persyaratan wajib memperoleh gelar sarjana. Dalam menyelesaikan skripsi ini mahasiswa dibimbing dan diarahkan oleh dosen pembimbing skripsi. Dosen pembimbing berasal dari dosen tetap program studi dan beberapa dosen tidak tetap yang memiliki kepakaran sesuai dengan tema penelitian mahasiswa.

Banyak literatur yang membahas tentang permasalahan skripsi pada mahasiswa terkait dengan dosen pembimbing. Salah satu determinan masa penulisan skripsi mahasiswa adalah cara bimbingan dosen. Bimbingan dosen yang baik pada penulisan skripsi memiliki pengaruh 6x mempercepat masa penulisan skripsi (Fathonah et al., 2011). Penelitian Hartanto dan Aisyah, (2016) menyatakan bahwa salah satu faktor yang berpengaruh positif dalam penyelesaian skripsi mahasiswa adalah kualitas bimbingan skripsi oleh dosen pembimbing. Sementara 
pada penelitian Zulkifli, (2012) diperoleh bahwa persepsi mahasiswa tentang peranan dosen pembimbing skripsi berada pada kategori baik dan sangat baik begitu juga dengan kualitas bimbingan skripsi. Namun perlu peningkatan peranan dan kualitas bimbingan dosen pembimbing pada aspek penulisan ilmiah skripsi.

Dosen pembimbing skripsi di program studi Sarjana Keperawatan STIKes Hang Tuah Pekanbaru telah ditetapkan sesuai dengan keilmuannya masing-masing. Setiap dosen dibebankan 3-4 mahasiswa sebagai pembimbing satu dan 2-3 mahasiswa sebagai pembimbing 2. Dosen pembimbing diberikan arahan dan persamaan persepsi tentang tugas dan tanggung jawabnya dalam proses bimbingan skripsi oleh koordinator mata kuliah Skripsi. Diharapkan dengan ini setiap dosen memiliki persepsi yang sama tentang proses pembimbingan dalam melaksanakan tugasnya pada mata kuliah skripsi terhadap mahasiswa bimbingannya (Program Studi Sarjana Keperawatan STIKes Hang Tuah Pekanbaru, 2020).

Berdasarkan wawancara dengan 3 orang mahasiswa prodi S1 Keperawatan yang belum menyelesaikan Skripsi selama satu tahun pada tahun ajaran 2018/2019, diperoleh data bahwa ketiga mahasiswa tersebut mengatakan kendala mereka adalah motivasi diri sendiri yang naik turun dan dosen pembimbing yang susah dijumpai. Dua dari tiga mahasiswa mengatakan dosen pembimbing terkadang tidak menepati waktu bimbingan yang telah disepakati, dosen pembimbingnya memiliki maksud yang berbeda dengan keinginan mahasiswa dalam penelitiannya. Sementara satu orang mahasiswa lagi mengatakan dosen pembimbing memiliki karakter yang susah dipahami oleh mahasiswa. Mahasiswa terkadang susah mengerti maksud yang disampaikan oleh pembimbing saat tatap muka. Mahasiswa terpaksa meminta ijin untuk merekam perbincangan yang terjadi saat bimbingan yang kemudian akan diulang lagi dirumah untuk memahami maksud pembimbing tersebut.

Data dari bidang akademik prodi S1 Keperawatan STIKes Hang Tuah Pekanbaru tahun 2020 diperoleh data bahwa masa 
menyelesaikan skripsi pada 5 dari 58 mahasiswa yang lulus Sarjana Keperawatan (S.Kep) tahun ajaran 2016/2017 adalah selama 3 semester, 1 dari 41 lulusan S.Kep tahun ajaran 2017/2018 selama 3 semester dan 1 dari 39 lulusan S.Kep tahun ajaran 2018/2019 adalah selama 3 semester. Seharusnya masa penugasan skripsi yang dibebankan kepada mahasiswa adalah satu semester (6 bulan). Hal ini tentunya berdampak terhadap perpanjangan masa studi S.Kep mahasiswa tersebut. Pada tahun ajaran 2016/2017 terdapat beberapa pergantian dosen pembimbing yang disebabkan oleh permintaan dari dosen yang bersangkutan karena ketidaksanggupan melanjutkan bimbingan pada mahasiswa yang tidak mengikuti arahannya. Selain itu pergantian juga disebabkan karena dosen yang bersangkutan melanjutkan pendidikan Magister Keperawatan di pulau Jawa.

Penelitian ini bertujuan untuk mengetahui hubungan penilaian kinerja dosen dalam bimbingan skripsi dengan kualitas skripsi

\section{METODE PENELITIAN}

Metode penelitian yang digunakan adalah jenis penelitian kuantitatif analitik, dengan desain korelasi dan pendekatan cross sectional. Penelitian ini mendapatkan pengaruh variabel independen (kinerja dosen dalam bimbingan skripsi) terhadap variabel dependen (kualitas skripsi mahasiswa). Penelitian ini dilakukan di Program studi Sarjana Keperawatan STIKes HTP. Populasi penelitian ini adalah seluruh lulusan Sarjana Keperawatan STIKes HTP tahun 2019 yang berjumlah 38 mahasiswa dan lulusan Sarjana Keperawatan tahun 2020 sebanyak 39 mahasiswa sehingga jumlah keseluruhan 77 orang alumni. Sampel yang pada penelitian ini adalah seluruh lulusan Sarjana Keperawatan STIKes HTP tahun 2019 dan 2020. Teknik pengambilan sampel menggunakan Total Sampling. Pengambilan sampel berdasarkan kriteria inklusi penelitian, yakni: lulusan Sarjana Keperawatan STIKes HTP tahun 2019 dan 2020 yang masih aktif sebagai mahasiswa profesi Ners STIKes HTP tahun 2019-2020 dan 2020-2021.

Variabel pada penelitian ini terdapat 
Siska Mayang Sari, Ennimay, Penilaian Kinerja Dosen dalam Bimbingan Skripsi

variabel independen dan variabel dependen. Variabel independen yakni kinerja dosen dalam bimbingan skripsi. Sementara itu variabel dependen adalah kualitas skripsi. Analisis data menggunakan uji chi-square. Etika penelitian yang dilakukan oleh peneliti dalam penelitian ini adalah mengajukan informed consent (persetujuan menjadi responden), menggunakan benefeciency (bermanfaat bagi responden) serta confidentiality (kerahasiaan). Sebelum melakukan pengambilan data, penelitian ini telah dilakukan uji etik pada komisi etika penelitian Kesehatan STIKes Hang Tuah Pekanbaru dengan SK. Nomor: 677/KEPK/STIKes-HTP/X/2020

\section{HASIL PENELITIAN}

Berikut hasil univariat setiap variabel penelitian:

\section{Tabel 1}

Hasil univariat variabel penelitian

\begin{tabular}{lcc}
\hline Komponen & $\begin{array}{c}\text { Freku } \\
\text { ensi }\end{array}$ & $\begin{array}{c}\text { Persent } \\
\text { ase (\%) }\end{array}$ \\
\hline Karakteristik Responden & & \\
\hline a. Angkatan & & \\
$\quad$ Angkatan 2015 & 38 & 49,4 \\
Angkatan 2016 & 39 & 50,6
\end{tabular}

\begin{tabular}{lcc}
\hline Komponen & $\begin{array}{c}\text { Freku } \\
\text { ensi }\end{array}$ & $\begin{array}{c}\text { Persent } \\
\text { ase (\%) }\end{array}$ \\
\hline Karakteristik Responden & & \\
\hline b. Jenis Kelamin & & \\
$\quad$ Perempuan & 67 & 87 \\
$\quad$ Laki-laki & 10 & 13 \\
\hline Variabel Independen & & \\
Kinerja Dosen Pembimbing 1 & & \\
$\quad$ Baik & 45 & 58,4 \\
$\quad$ Kurang Baik & 32 & 41,6 \\
Kinerja Dosen Pembimbing 2 & & \\
$\quad$ Baik & 45 & 58,4 \\
$\quad$ Kurang Baik & 32 & 41,6 \\
\hline Variabel Dependen & & \\
Kualitas Skripsi mahasiswa & & \\
- A & 46 & 59,7 \\
- A- & 23 & 29,9 \\
- B+ & 5 & 6,5 \\
- B & 3 & 3,9 \\
\hline
\end{tabular}

Pada tabel 1 di atas menunjukkan bahwa responden terbanyak berasal dari Angkatan 2016 yakni sejumlah 39 orang (50,6\%), umumnya berjenis kelamin perempuan yakni sebanyak 67 orang (87\%). Kinerja dosen pembimbing 1 dan 2 dalam membimbing skripsi menurut penilaian mahasiswa umumnya pada kategori baik yakni sejumlah 45 orang $(58,4 \%)$. Sementara itu kualitas nilai skripsi mahasiswa sebagian besar memperoleh nilai A yakni sejumlah 46 orang $(59,7 \%)$. 


\section{Tabel 2}

Hasil univariat sebaran item kinerja dosen pembimbing skripsi

\begin{tabular}{lllll}
\hline Komponen & \multicolumn{2}{l}{ Pembimbing } & Pembimbing 2 \\
Kinerja & $\mathbf{1}$ & & & \\
\cline { 2 - 5 } & $\mathbf{F}$ & $\mathbf{\%}$ & $\mathbf{F}$ & $\mathbf{\%}$ \\
\hline Waktu & & & & \\
bimbingan & & & & \\
Baik & 53 & 68,8 & 54 & 70,1 \\
Kurang & 24 & 31,2 & 23 & 29,9 \\
\hline Proses & & & & \\
bimbingan & & & & \\
Baik & 40 & 51,9 & 48 & 62,3 \\
Kurang & 37 & 48,1 & 29 & 37,7 \\
\hline Media & & & & \\
bimbingan & & & & \\
Tatap muka & 46 & 59,7 & 46 & 59,7 \\
Japri (WA/ & 22 & 28,6 & 24 & 31,2 \\
Line & & & & \\
Group) & & & & \\
By Telepon & 4 & 5,2 & 4 & 5,2 \\
Sharing & 3 & 3,9 & 3 & 3,9 \\
pengalaman & & & & - \\
Dll & 2 & 2,6 & - & \\
\hline & & & & \\
\hline
\end{tabular}

Berdasarkan tabel 2 tersebut, dapat dilihat bahwa penilaian kinerja dosen pembimbing skripsi berdasarkan item kinerja menurut penilaian mahasiswa adalah umumnya pembimbing 1 memiliki waktu bimbingan yang baik yakni sebesar 53 orang $(68,8 \%)$ dan pembimbing 2 juga menyediakan waktu bimbingan yang baik sebesar 54 orang $(70,1 \%)$. Sementara pada item proses bimbingan skripsi mahasiswa menilai pembimbing 1 memiliki proses yang baik yakni sebesar 40 orang $(51,9 \%)$ dan pembimbing 2 juga dengan proses bimbingan yang baik sejumlah 48 orang (62,3\%). Pada pemilihan media bimbingan mahasiswa umumnya menilai pembimbing 1 dengan tatap muka sebesar 46 orang $(59,7 \%)$ dan pembimbing 2 juga tatap muka sejumlah 46 orang $(59,7 \%)$.

Tabel 3.

Uji bivariat

\begin{tabular}{|c|c|c|c|c|c|c|c|c|c|c|c|c|}
\hline \multirow{3}{*}{$\begin{array}{l}\text { Variabel } \\
\text { Kinerja }\end{array}$} & & \multicolumn{8}{|c|}{ Kualitas Skripsi } & \multicolumn{2}{|c|}{ Jumlah } & \multirow[t]{2}{*}{ Pvalue } \\
\hline & & \multicolumn{2}{|l|}{$\mathbf{A}$} & \multicolumn{2}{|l|}{ A- } & \multicolumn{2}{|c|}{$\mathbf{B}+$} & \multicolumn{2}{|l|}{ B } & \multirow[b]{2}{*}{$\mathbf{F}$} & \multirow[b]{2}{*}{$\%$} & \\
\hline & Dosen & $\mathbf{F}$ & $\%$ & $\mathbf{F}$ & $\%$ & $\mathbf{F}$ & $\%$ & $\mathbf{F}$ & $\%$ & & & \\
\hline \multicolumn{13}{|c|}{ Pembimbing1 } \\
\hline Baik & & 31 & 40,2 & 10 & 13 & 3 & 3,9 & 1 & 1,3 & 45 & 58,4 & 0,219 \\
\hline Kurang Baik & & 15 & 19,5 & 13 & 16,9 & 2 & 2,6 & 2 & 2,6 & 32 & 41,6 & \\
\hline Total & & 46 & 59,7 & 23 & 29,9 & 5 & 6,5 & 3 & 3,9 & 77 & 100 & \\
\hline
\end{tabular}


Siska Mayang Sari, Ennimay, Penilaian Kinerja Dosen dalam Bimbingan Skripsi

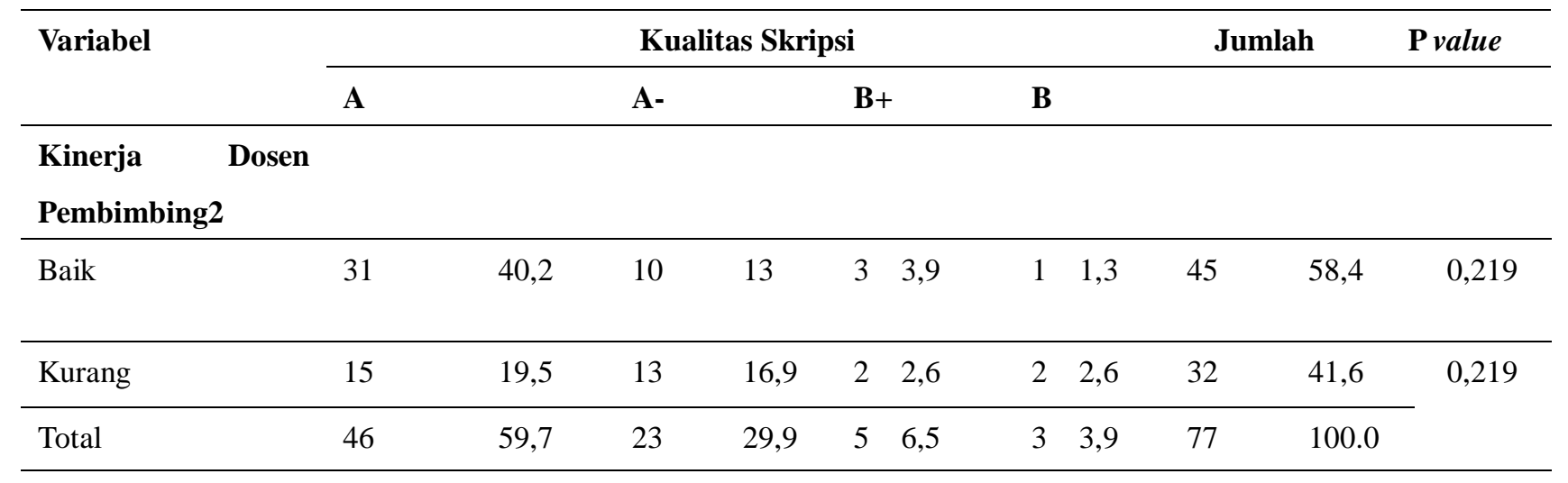

Tabel 3 menunjukkan hasil uji bivariat chi-square antara variabel independen dan variabel dependen. Hasil uji chi-square antara kinerja dosen pembimbing 1 dengan kualitas skripsi diperoleh p-value 0,219 (>0,05), yang memiliki makna bahwa tidak terdapat hubungan antara kinerja dosen pembimbing1 skripsi dengan kualitas skripsi mahasiswa.

Pada tabel yang sama juga dapat dilihat bahwa hasil hasil uji chi-square antara kinerja dosen pembimbing 2 dengan kualitas skripsi diperoleh p-value 0,219 (>0,05), yang bermakna bahwa tidak terdapat hubungan antara kinerja dosen pembimbing 2 skripsi dengan kualitas skripsi mahasiswa.

\section{PEMBAHASAN}

Pada hasil penelitian diperoleh bahwa responden berasal dari Angkatan 2015 dan 2016. Kedua Angkatan ini belum pernah dilakukan penilaian kinerja dosen dalam membimbing skripsi berdasarkan persepsi mahasiswa. Saat penelitian berlangsung Angkatan 2015 merupakan alumni Ners di tahun ajaran 2020/2021 yang saat itu sedang menanti pengumuman kelulusan ujian kompetensi Ners Indonesia. Sementara Angkatan 2016 yang menjadi responden adalah yang sedang mengikuti pendidikan profesi Ners tahun ajaran 2020/2021. Kedua angkatan ini memiliki kesempatan yang sama dalam menjadi responden penelitian dan tidak ada perbedaan perlakuan pada penelitian.

Responden penelitian umumnya berjenis kelamin perempuan. Hal ini menunjukkan bahwa calon perawat Ners dari STIKes Hang Tuah Pekanbaru pada umumnya berjenis kelamin perempuan. Dengan artikata bahwa tenaga perawat didominasi oleh perempuan. Dapat dikaitkan dengan sifat mother instinct 
yang dimiliki oleh perempuan sangat bermakna dalam memberikan pelayanan keperawatan seorang perawat kepada pasiennya. Layaknya seorang ibu, perawat memberikan pelayanan dan kasih sayang kepada pasienya dengan tulus ikhlas demi kesembuhan dan kesehatan pasien. Hal ini didukung dengan tokoh perawat pertama dunia yakni Florence Nightingale yang notabene adalah seorang perempuan. Sebagai pelopor perawat modern dunia Florence Nightingale tanpa rasa takut memberikan pelayanan jasa kepada para tentara yang terluka di medan perang Krimea, Semenanjung Krimeea, Rusia. Teori keperawatan Florence Nightingale yang dikenal dengan Environmental Nightingale mengemukakan bahwa praktik keperawatan professional harus mengaplikasikan empat konsep utama yakni: pasien (orang yang menerima asuhan keperawatan), lingkungan, kesehatan dan keperawatan itu sendiri. Keempat konsep ini saat ini dikenal dengan paradigma keperawatan menurut Nightingale. (Alligood, M.R., 2013).

Penilaian kinerja dosen dalam membimbing skripsi menurut persepsi mahasiswa untuk masing-masing pembimbing 1 dan 2 berada pada kategori baik. Hal ini didukung dengan proses bimbingan dan waktu bimbingan yang baik oleh pembimbing. Pada penelitian ini mahasiswa menilai setiap dosen pembimbing telah melakukan kinerja dengan baik dalam membimbing skripsi. Mahasiswa menyatakan dosen telah melakukan bimbingan sesuai dengan waktu yang telah ditetapkan oleh program studi dan kesepakatan antara mahasiswa dan dosen pembimbing. Berdasarkan jawaban responden rerata dosen memberikan umpan balik konsultasi skripsi kurang lebih 2-3 hari. Waktu ini termasuk cepat sehingga tidak memperlama waktu bimbingan. Selain itu dosen juga sangat baik menyediakan waktu khusus untuk bimbingan skripsi mahasiswa. Hal ini sangat mendukung proses konsultasi yang baik sehingga pemahaman mahasiswa tentang materi dan topik konsultasi terkait skripsinya dapat menjadi lebih baik. Sejalan dengan penelitian Ristianti (2017) yang menyatakan bahwa untuk menjalin kerjasama hubungan interpersonal antara mahasiswa dan dosen dalam bimbingan skripsi salah satu hal yang 
diperlukan adalah ketersediaan waktu bimbingan yang adekuat. Dengan adanya waktu bimbingan yang adekuat akan terjalin hubungan interpersonal yang baik antara keduanya sehingga akan berdampak baik terhadap skripsi mahasiswa.

Sementara itu penilaian kinerja dosen dalam bimbingan skripsi menurut persepsi mahasiswa untuk setiap pembimbing 1 dan 2 pada item kinerja proses bimbingan berada pada kategori baik. Responden menilai dosen pembimbing sangat baik dalam mempersiapkan diri dalam proses bimbingan serta menguasai materi skripsi yang dibimbing. Persiapan ini dinilai mahasiswa sangat mendukung kualitas bimbingan skripsi. Kemampuan yang dimiliki dosen ini merupakan salah satu kompetensi dosen yang termasuk dalam kinerja dosen dalam menerapkan tri dharma perguruan tinggi (Mendikbud RI, 2020).

Selain itu, pada penelitian ini mahasiswa juga menilai baik proses bimbingan dosen dalam bimbingan skripsi dalam hal memotivasi mahasiswa mengerjakan skripsi. Motivasi ini sangat dibutuhkan mahasiswa dari seorang dosen pembimbing, karena mahasiswa berharap besar kepada dosen pembimbing untuk memberikan yang terbaik selama bimbingan skripsi sehingga kualitas skripsi yang dihasilkan sesuai harapan mahasiswa. Hasil ini sejalan dengan penelitian Lestari (2012) bahwa ada hubungan yang positif dan signifikan antara harapan mahasiswa kepada dosen pembimbing dengan motivasi menulis skripsi.

Penelitian ini juga diperoleh penilaian mahasiswa terkait kinerja dosen dalam bimbingan skripsi pada item proses bimbingan bahwa dosen telah baik dalam memberikan solusi dan alternatif pemecahan masalah yang dihadapi mahasiswa selama menyelesaikan skripsi. Permasalahan yang sering dihadapi mahasiswa dalam menyelesaikan skripsi umumnya adalah keterbatasan dalam menuangkan ide pada tulisan ilmiah sesuai EYD, pengolahan data secara statistik, penulisan pembahasan serta keterbatasan dalam menemukan referensi/ jurnal terkait. Menurut penilaian mahasiswa dosen prodi S1 Keperawatan STIKes Hang Tuah Pekanbaru telah dengan baik memberikan solusi dari 
semua permasalahan tersebut. Dosen mengarahkan, menjelaskan dan menuntun mahasiswa untuk mengatasi masalah tersebut. Permasalahan-permasalahan kesulitan skripsi ini juga dikemukakan oleh penelitian Rismen (2015) yang mengemukakan bahwa sejumlah $66,7 \%$ mahasiswa kesulitan dalam menuangkan ide dalam tulisan ilmiah, sebanyak $61,54 \%$ kesulitan dalam mengolah data secara statistik dan sebesar $64,1 \%$ mahasiswa kesulitan dalam menarasikan hasil penelitian.

Penilaian kinerja dosen dalam bimbingan skripsi item media bimbingan menurut mahasiswa umumnya memilih tatap muka. Dengan tatap muka secara langsung akan mengoptimalkan komunikasi antara mahasiswa dan dosen selama proses bimbingan. Namun, pada pandemi COVID-19 konsultasi bimbingan skripsi tatap muka dibatasi sesuai edaran Kemendikbud RI (2020) maka bimbingan tatap muka luar jaringan (luring) dialihkan pada online/ dalam jaringan (daring). Media bimbingan yang dilakukan mahasiswa adalah WhatsApp group/ LINE group, chating pribadi (jaringan pribadi/Japri),

email, google meet dan zoom meeting. Selain itu, dosen juga berbagi pengalaman/ sharing pengalamannya selama melakukan penelitian. Pengalaman ini diharapkan menjadi bahan masukan dan refleksi mahasiswa dalam menyusun skripsi dan melakukan penelitian. Hasil penelitian ini sesuai dengan penelitian Saputra, (2018) diperoleh bahwa perlunya menerapkan komunikasi dengan kemudahan seperti whats app (WA), membuat grup bimbingan pada dosen pembimbing yang sama, melakukan bimbingan tatap muka supaya informasi yang diperoleh lebih jelas dan interaksi langsung antara keduanya, serta sharing pengalaman penelitian antara dosen kepada mahasiswa.

Pada hasil uji chi-square antara kinerja dosen pembimbing 1 dan 2 dengan kualitas skripsi diperoleh nilai p-value 0,219 (>0,05), yang memiliki makna bahwa tidak terdapat hubungan antara kinerja dosen pembimbing skripsi dengan kualitas skripsi mahasiswa. Pada penelitian ini mahasiswa yang mempersepsikan kinerja dosen dalam bimbingan skripsi baik memiliki kualitas nilai skripsi A, namun mahasiswa yang 
Siska Mayang Sari, Ennimay, Penilaian Kinerja Dosen dalam Bimbingan Skripsi

mempersepsikan kinerja dosen dalam

bimbingan skripsi krang baik juga memiliki

kualitas nilai skripsi A. Maknanya kualitas nilai skripsi tidak berhubungan dengan baik atau tidaknya kinerja dosen dalam bimbingan skripsi. Penilaian kualitas skripsi mahasiswa bukan hanya dari nilai bimbingan dari dosen pembimbing tetapi juga terdapat perbandingan dari nilai ujian proposal dan ujian sidang hasil skripsi. Nilai ujian proposal dan nilai sidang hasil skripsi diberikan oleh setiap penguji dari 3 orang penguji, yang mana salah satunya adalah dosen pembimbing 1 sebagai ketua penguji, sehingga penilaian tidak berasal dari dosen pembimbing tetapi juga berasal dari dua dosen lainnya sebagai penguji 1 dan penguji 2 . (Program Studi Sarjana Keperawatan STIKes Hang Tuah Pekanbaru, 2020).

\section{SIMPULAN}

Hasil uji chi-square antara kinerja dosen pembimbing 1 dan 2 dengan kualitas skripsi diperoleh niłai p-value 0,219 (>0,05), yang memiliki makna bahwa tidak terdapat hubungan antara kinerja dosen pembimbing skripsi dengan kualitas skripsi mahasiswa.

\section{SARAN}

Diharapkan kepada prodi S1 Keperawatan STIKes Hang Tuah Pekanbaru untuk menerapkan penilaian kinerja dosen dalam bimbingan skripsi sebagai salah satu upaya evaluasi bimbingan skripsi dan kinerja dosen

\section{DAFTAR PUSTAKA}

Alligood, M.R., (2013). Nursing theory. Utilization \& application. 5 edition. St.Louis, Missouri: Elsevier

Dikti, K. (2019). Rubrik beban kerja dosen (BKD).

Fathonah, S., Wahyuningsih, S. E., Wahyuningsih, U., Teknologi, J., \& Semarang, U. N. (2011). Determinan Masa Penulisan Skripsi Mahasiswa Prodi PKK. Jurnal Kompetensi Teknik, 2(2), 127-136.

Hartanto, U., \& Aisyah, M. N. (2016). Faktor-faktor yang mempengaruhi penyelesaian skripsi mahasiswa pendidikan akuntansi UNY. Jurnal Pendidikan Akuntansi Indonesia, XIV(1).

Lestari, N.A.,(2012). Hubungan ekspekstasi terhadap dosen pembimbing dengan motivasi menulis skripsi. Educational Pschycology Journal. 1(1). 1-8.

Mendikbud RI. (2020). Peraturan Menteri Pendidikan Dan Kebudayaan Republik Indonesia Nomor 3 Tahun 2020 Tentang Standar Nasional Pendidikan Tinggi. In Menteri Pendidikan dan Kebudayaan RI 
(pp. 1-76).

Peraturan Pemerintah RI. (2009). Peraturan Pemerintah Republik Indonesia Nomor 37 Tahun 2009 Tentang Dosen. ???

Presiden Republik Indonesia. (2012). Undang Undang Republik Indonesia Nomor 12 Tahun 2012.

Program Studi Sarjana Keperawatan STIKes Hang Tuah Pekanbaru. (2018). Buku Panduan Akademik Program Studi Sarjana Keperawatan T.A 2018-2019.

Program Studi Sarjana Keperawatan STIKes Hang Tuah Pekanbaru. (2020). Panduan Skripsi Program Studi Sarjana Keperawatan (Issue 5).

Rismen, S. (2015). Analisis kesulitan mahasiswa dalam penyelesaian skripsi di Prodi Matematika STKIP PGRI. LEMMA. 1(2). 57-62.

Ristianti, D.H., (2017). Analisis hubungan interpersonal mahasiswa terhadap dosen dalam proses bimbingan skripsi. Islamic Counseling. Vol 1(1). 25-40

Saputra, R. (2018). Pola komunikasi dosen dan mahasiswa dalam bimbingan skripsi. JISIP: Jurnal Ilmu Sosial Dan Ilmu Politik, 7(2), 109-114.

STIKes Hang Tuah Pekanbaru. (2018a). Peraturan Akademik STIKes Hang Tuah Pekanbaru.

STIKes Hang Tuah Pekanbaru. (2018b). STATUTA STIKes HANG TUAH PEKANBARU.

Zulkifli, N. (2012). Persepsi mahasiswa tentang peranan dosen pembimbing dalam pembuatan tugas akhir (skripsi) mahasiswa. EDUCHILD, 01(1), 50-58. 